A C G Rec. Nat. Prod. 12:2 (2018) 190-194

\title{
Antileishmanial Activity of a New ent-Kaurene Diterpene Glucoside Isolated from Leaves of Xylopia excellens R.E.Fr. (Annonaceae)
}

\author{
Danielle C. de Alencar ${ }^{\circledR 1}$, Felipe M. A. da Silva ${ }^{\circledR 1, *}$, Richardson A. de \\ Almeida $^{\oplus 1}$, Emmanoel V. Costa ${ }^{\oplus 1}$, Lívia M. Dutra ${ }^{\oplus 2}$, Andersson Barison ${ }^{\oplus 2}$, \\ Helito Volpato $^{\oplus 3}$, Celso V. Nakamura ${ }^{\oplus 3}$, Hector H. F. Koolen ${ }^{\oplus 4}$, \\ Afonso Duarte L. de Souza ${ }^{\oplus 1}$ and Maria Lúcia B. Pinheiro ${ }^{\oplus 1, *}$ \\ ${ }^{1}$ Departamento de Química, Universidade Federal do Amazonas, 69077-000, Manaus, AM, \\ Brasil \\ ${ }^{2}$ Centro de RMN, Universidade Federal do Paraná, 81531-990, Curitiba, PR, Brasil \\ ${ }^{3}$ Laboratório de Inovação Tecnológica no Desenvolvimento de Fármacos e Cosméticos, \\ Universidade Estadual de Maringá, 87020-900, Maringá, PR, Brasil \\ ${ }^{4}$ Metabolomics and Mass Spectrometry Research Group, Universidade do Estado do \\ Amazonas, 69050-010, Manaus, AM, Brasil
}

(Received June 19, 2017; Revised August 21, 2017; August 31, 2017)

\begin{abstract}
This work describes a new ent-kaurene diterpene glucoside, $7 \beta-O$ - $\beta$-D-glucopyranoside-ent-kaur-16ene, from the leaves of Xylopia excellens R.E.Fr. (Annonaceae). The compound showed high in vitro antileishmanial activity ( $\mathrm{IC}_{50}$ of $15.23 \pm 0.64 \mu \mathrm{g} / \mathrm{mL}$ ) towards promastigote forms of Leishmania amazonensis, and low cytotoxicity against J774A1 cells (SI of 1.96).
\end{abstract}

Keywords: Annonaceae; ent-kaurene diterpene; Leishmania amazonensis; Xylopia excellens. (C) 2018 ACG Publications. All rights reserved.

\section{Plant Source}

Leaves of $X$. excellens R.E.Fr. were collected in the Campus of the Universidade Federal do Amazonas (UFAM), in July 2011. The specimen was identified by Dr. Antonio Carlos Webber from UFAM. A voucher specimen was deposited in the herbarium of UFAM under registration number 8249

\section{Previous Studies}

Xylopia is one of the most representative genera of the Annonaceae family and comprises approximately 157 tree and shrub species distributed in the pantropical region [1]. Several species are

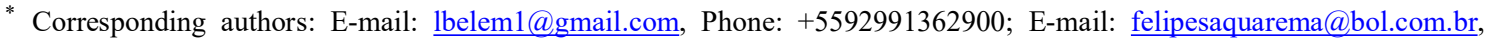
felipemas@ufam.edu.br; Phone: +55929982517341.
} 
employed in popular medicine with a remarkable set of purposes [2,3]. Previous phytochemical investigations report this genus as source of biologically active diterpenes [4,5]. However, Xylopia excellens R.E.Fr. (Annonaceae), popularly known as "envira amarela", is an Amazon species which has not yet been chemically and biologically studied.

Leishmaniasis has been considered the second most important protozoal disease by the World Health Organization (WHO). The search for new model compounds for the development of alternative drugs that exhibit potential leishmanicidal activity is growing, once causative agents of its various clinical manifestations present increasing rates of resistance to conventional treatments. Beyond this, the number of commercially available drugs for the treatment of chronic diseases still is below a satisfactory number [6]. In our continuous search for new biologically active compounds from Amazonian plants [7-9], this work reports a new ent-kaurene diterpene glucoside from Xylopia excellens R.E.Fr. and its evaluation against promastigote forms of Leishmania amazonensis.

\section{Present Study}

General procedure: One-dimensional (1D) and two-dimensional (2D) nuclear magnetic resonance (NMR) spectroscopy data were acquired with a Bruker AVANCE III 600 NMR spectrometer, operating at $14.1 \mathrm{~T}$, observing ${ }^{1} \mathrm{H}$ at $600 \mathrm{MHz}$ and ${ }^{13} \mathrm{C}$ at $150 \mathrm{MHz}$. All ${ }^{1} \mathrm{H}$ and ${ }^{13} \mathrm{C} \mathrm{NMR}$ experiments were obtained in $\mathrm{CD}_{3} \mathrm{OD}$ or $\mathrm{CDCl}_{3}$. Chemical shifts $(\delta)$ are given in ppm relative to the TMS and coupling constants $(J)$ are given in Hertz. High resolution atmospheric pressure chemical ionization mass spectrometry (APCI-HRMS) measurements were recorded on a Waters Synapt HDMS instrument with quadrupole time-of-flight geometry. Optical rotation was determined on a Jasco P1020 polarimeter. Fourier transform infrared (FTIR) spectra were measured on a FTLA2000-104 spectrophotometer. Silica gel 60 (70-230 mesh) was used for column chromatography, while silica gel 60 F254 was used for analytical $(0.25 \mathrm{~mm})$ thin layer chromatography (TLC). The spots were revealed with vanillin-sulphuric acid reagent.

Extraction and Isolation: The plant material was dried over an oven with air circulation at $50{ }^{\circ} \mathrm{C}$ for $24 \mathrm{~h}$ and powdered. The powdered material $(1,000 \mathrm{~g})$ was macerated for three days with $n$-hexane (solvent renewal every day), being the extracts concentrated under reduced pressure at $50{ }^{\circ} \mathrm{C}$ and combined $(13.2 \mathrm{~g})$. An aliquot $(5 \mathrm{~g})$ was partitioned with hexane $/ 10 \%$ aqueous methanol $(1: 1)$, yielding the hydroalcoholic fraction $(1.7 \mathrm{~g})$. The hydroalcoholic fraction was fractionated over a silica gel column eluted initially with n-hexane, followed by an increasing polarity gradient of ethyl acetate and methanol, affording 1 (AcOEt/MeoH 1:1, 148.5 mg).

Antileishmanial Activity Assay: Promastigote forms of Leishmania amazonensis (MHOM/BR/75/JOSEFA) [10] were maintained by weekly transfers in Warren's medium supplemented with $10 \%$ heat-inactivated fetal bovine serum (FBS) at $25{ }^{\circ} \mathrm{C}$ in a tissue flask. $L$. amazonensis promastigotes $\left(1 \times 10^{6}\right.$ parasites $\left./ \mathrm{mL}\right)$ with $48 \mathrm{~h}$ cultivated were inoculated in a 96-well plate containing Warren's medium supplemented with $10 \%$ inactivated fetal bovine serum with different concentrations of 1 , and incubated at $25{ }^{\circ} \mathrm{C}$ for $72 \mathrm{~h}$. After treatment, the cells were incubated with XTT $(0.5 \mathrm{mg} / \mathrm{mL})$ and PMS $(0.06 \mathrm{mg} / \mathrm{mL})$ for $4 \mathrm{~h}$ at $25{ }^{\circ} \mathrm{C}$. The viable cells were measured using a Bio-Tek Power Wave XS spectrophotometer, by absorbance at $450 \mathrm{~nm}$. The results were expressed by $\mathrm{IC}_{50}$ (concentration that inhibited 50\% parasite growth). Amphotericin was used as positive control.

Cytotoxicity Assay: J774A1 macrophages [11], obtained from confluent cultures, were cultured at $5 \times 10^{5}$ cells $/ \mathrm{mL}$ in RPMI 1640 medium supplemented with $10 \%$ FBS in 96-well microplates at $37^{\circ} \mathrm{C}$ in a $5 \% \mathrm{CO}_{2}$ atmosphere. After $24 \mathrm{~h}$, the cells were treated with different concentrations of 1 and incubated for $48 \mathrm{~h}$. The microplates were then washed with PBS, and incubated with MTT solution (2 
$\mathrm{mg} / \mathrm{mL}$ ). The precipitate was solubilized in DMSO, and absorbance was read in a Bio-Tek Power Wave XS spectrophotometer at $492 \mathrm{~nm}$. The cytotoxicity concentration for $50 \%\left(\mathrm{CC}_{50}\right)$ of the cells was determined. The selectivity index (SI) was calculated as $\mathrm{CC}_{50} / \mathrm{IC}_{50}$.

Statistical Analysis: The means and standard deviations were determined from at least three experiments. All tests were done in duplicate. Statistical analysis was performed with the program GraphPad Prism 4. Students t test was applied, and a $p$ value less than 0.05 was regarded as significant.

Compound diterpene glucoside was obtained as a colorless amorphous solid with molecular formula $\mathrm{C}_{26} \mathrm{H}_{42} \mathrm{O}_{6}$, as determined by HRMS $m / z 451.3049[\mathrm{M}+\mathrm{H}]^{+}$and NMR data. The IR spectrum of 1 shows typical absorptions of hydroxyl and $\mathrm{C}=\mathrm{C}$ double bond groups. The ${ }^{13} \mathrm{C}$ NMR spectrum showed 26 signals, including six typical signals for a glucose moiety $\left(\delta_{\mathrm{C}} 63.2,72.1,76.1,77.9,78.4\right.$, and 106.6). Structure of the diterpene glucoside was identified as an ent-kaurene diterpene presenting the specific optical deviation $\left([\alpha]=-156.1^{\circ}\right)$, based on NMR data and the spectroscopic pattern of diterpenes from the Xylopia genus [12-14]. The ${ }^{1} \mathrm{H}$ NMR spectrum shows typical methyl groups at $\delta_{\mathrm{H}}$ $0.83(\mathrm{H}-19), 0.87(\mathrm{H}-18)$, and $1.07(\mathrm{H}-20)$, besides hydrogen signals of exocyclic double bond at $\delta_{\mathrm{H}}$ $4.74(\mathrm{H}-17 \mathrm{a})$ and $4.77(\mathrm{H}-17 \mathrm{~b})$ [15]. The hydrogen signal at $\delta_{\mathrm{H}} 4.28\left(1 \mathrm{H}, \mathrm{d}, J=7.7 \mathrm{~Hz}, \mathrm{H}-1^{\prime}\right)$ exhibits besides the characteristic chemical shift expected for $\beta$ anomeric hydrogens, a significantly larger $J$ value, which is consistent with the axial-axial coupling $[15,16]$, supporting the presence of a $\beta$-Dglucose moiety. HMBC experiment shows correlations of the hydrogen signals at $\delta_{\mathrm{H}} 4.74(\mathrm{H}-17 \mathrm{a})$ and $4.77(\mathrm{H}-17 \mathrm{~b})$ with the carbon atoms at $\delta_{\mathrm{C}} 34.8(\mathrm{C}-12), 45.3(\mathrm{C}-13), 46.7(\mathrm{C}-15)$, and $157.3(\mathrm{C}-16)$. The hydrogen signal at $\delta_{\mathrm{H}} 2.37(\mathrm{H}-15)$ correlates with carbon signals at $\delta_{\mathrm{C}} 40.0(\mathrm{C}-14), 45.3(\mathrm{C}-13), 89.7$ (C-7), 103.6 (C-17), and 157.3 (C-16), confirming the ent-kaurene skeleton and suggesting the glucose presence at $\mathrm{C}-7$ position. The glucose position was supported by the ${ }^{1} \mathrm{H}-{ }^{13} \mathrm{C}$ long-range correlation between H-1 $\left(\delta_{\mathrm{H}} 4.28\right)$ and C-7 $\left(\delta_{\mathrm{C}} 89.7\right)$, and correlations among H-7 $\left(\delta_{\mathrm{H}} 3.47\right)$ and C-5 $\left(\delta_{\mathrm{C}} 47.8\right), \mathrm{C}-$ $9\left(\delta_{\mathrm{C}} 52.5\right)$, and $\mathrm{C}-1^{\prime}\left(\delta_{\mathrm{C}} 106.6\right)$.

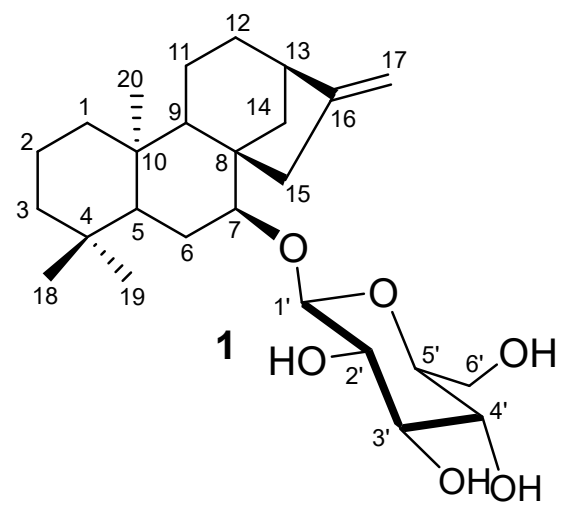

Figure 1. $7 \beta$-O- $\beta$-D-glucopyranoside-ent-kaur-16-ene isolated from Xylopia excellens.

The relative stereochemistry of the diterpene moiety was based on $1 \mathrm{D}$ NOE NMR experiments, obtained in $\mathrm{CDCl}_{3}$. The selective irradiation of the resonance frequency of the methyl hydrogen at $\delta_{\mathrm{H}} 1.02(\mathrm{H}-20 \mathrm{ax})$ shows mainly NOE enhancement on the signals at $\delta_{\mathrm{H}} 1.90(\mathrm{H}-14 \mathrm{ax})$, $1.71(\mathrm{H}-12 \mathrm{ax})$ and $0.81(\mathrm{H}-19 \mathrm{ax})$, which is compatible with ent-kaurane skeleton. The $7 \beta$ position for the glucosidic unit was stablished by the selective irradiation of the resonance frequency of the hydrogen signal at $\delta_{\mathrm{H}} 3.44(\mathrm{H}-7)$, which shows NOE enhancement on the signal at $\delta_{\mathrm{H}} 1.52(\mathrm{H}-6 \mathrm{ax})$, 1.99 (H-6eq), 1.16 (H-14eq), and 2.26 (H-15), in the aglicone moiety. Considering the NMR data and comparison with literature data [14], the structure of 1 corresponds to a new diterpene glucoside (7 $\beta$ $O$ - $\beta$-D-glucopyranoside-ent-kaur-16-ene). 
$7 \beta$-O- $\beta$-D-glucopyranoside-ent-kaur-16-ene (1): Colorless amorphous solid. $[\alpha]=-156.1(\mathrm{MeOH}, \mathrm{c}$ 0.005). IR (KBr) $v_{\max }=3377,2922,2872,1054 \mathrm{~cm}^{-1}$. HRMS $451.3049[\mathrm{M}+\mathrm{H}]^{+}$(calcd. $\mathrm{m} / z$ 451.3060). ${ }^{1} \mathrm{H}$ NMR (600 MHz, CD 3 OD): $\delta(\mathrm{ppm})=0.80(1 \mathrm{H}, \mathrm{m}, \mathrm{H}-1 \mathrm{a}), 0.83(3 \mathrm{H}, \mathrm{s}, \mathrm{H}-19), 0.87(3 \mathrm{H}, \mathrm{s}, \mathrm{H}-18)$, 1.07 (3H, s, H-20), 1.16 (1H, m, H-14a), 1.19 (1H, m, H-3a), 1.38 (1H, m, H-3b), 1.40 (1H, m, H-2a), $1.45(1 \mathrm{H}, \mathrm{m}, \mathrm{H}-12 \mathrm{a}), 1.47(1 \mathrm{H}, \mathrm{m}, \mathrm{H}-9), 1.52(1 \mathrm{H}, \mathrm{dt}, J=13.0,1.8 \mathrm{~Hz}, \mathrm{H}-6 \mathrm{a}), 1.58(2 \mathrm{H}, \mathrm{m}, \mathrm{H}-11)$, $1.60(1 \mathrm{H}, \mathrm{m}, \mathrm{H}-5), 1.68(1 \mathrm{H}, \mathrm{m}, \mathrm{H}-2 \mathrm{~b}), 1.74(1 \mathrm{H}, \mathrm{d}, J=11.9 \mathrm{~Hz}, \mathrm{H}-12 \mathrm{~b}), 1.81$ (1H, m, H-lb), 1.93 (1H, m, H-14b), 2.10 (1H, m, H-6b), $2.37(2 \mathrm{H}, \mathrm{m}, \mathrm{H}-15), 2.62$ (1H, m, H-13), 3.44 (1H, m, H-4 ) , 3.46 $\left(1 \mathrm{H}, \mathrm{m}, \mathrm{H}-3{ }^{`}\right), 3.47(1 \mathrm{H}, \mathrm{m}, \mathrm{H}-7), 3.53$ (1H, dd, $\left.J=9.7,7.7 \mathrm{~Hz}, \mathrm{H}-5{ }^{\prime}\right), 3.65(1 \mathrm{H}, \mathrm{m}, \mathrm{H}-6$ ' a), $3.72(1 \mathrm{H}$, m, H-6 b), $3.87\left(1 \mathrm{H}, \mathrm{m}, \mathrm{H}-2^{\prime}\right), 4.28\left(1 \mathrm{H}, \mathrm{d}, J=7.7 \mathrm{~Hz}, \mathrm{H}-1^{\prime}\right), 4.74(1 \mathrm{H}, \mathrm{m}, \mathrm{H}-17 \mathrm{a}), 4.77(1 \mathrm{H}, \mathrm{m}, \mathrm{H}-$ 17b). ${ }^{13} \mathrm{C}$ NMR (150 MHz, CD 3 OD): $\delta(\mathrm{ppm})=18.4(\mathrm{C}-20), 18.9$ (C-11), 20.0 (C-2), 22.5 (C-19), 27.6 (C-6), 34.2 (C-4), 34.2 (C-18), 34.8 (C-12), 40.0 (C-14), 40.4 (C-10), 41.7 (C-1), 43.5 (C-3), 45.3 (C13), 46.7 (C-15), 47.8 (C-5), 50.1(C-8), 52.5 (C-9), 63.2 (C-6'), 72.1 (C-2'), 76.1 (C-5), 77.9 (C-4'), 78.4 (C-3'), 89.7 (C-7), 103.6 (C-17), 106.6 (C-1'), 157.3 (C-16).

Compound 1 was active against promastigote forms of $L$. amazonensis, being observed $\mathrm{CC}_{50}$ value of $15.23 \pm 0.64 \mu \mathrm{g} / \mathrm{mL}$ [17]. Additionally, low cytotoxicity against J774A1 macrophages was observed with $\mathrm{CC}_{50}$ and SI values $(29.97 \pm 2.72 \mu \mathrm{g} / \mathrm{mL}$ and 1.96 , respectively). According literature parameters [17], SI values lower than 1 indicate that the analyte is more toxic to peritoneal macrophages than to the parasites. SI values greater than 1 indicate higher selectivity against the parasites than against the peritoneal macrophages.

Several terpenoids, such as sesquiterpenes, diterpenes, and triterpenes, have in vitro antileishmanial activity. However, ent-kaurane type and kaurene diterpenoids, including those which have sugar moiety, did not show significant activities on previous studies [18]. The activity recorded for 1 suggest that the position of glycoside moieties at C-7 can play an important role on the leishmanicidal activity. Further investigation is required in order to confirm this observation.

\section{Acknowledgments}

The authors are grateful to to CAPES, CNPq, FINEP and FAPEAM for financial support.

\section{Supporting Information}

Supporting Information accompanies this paper on http://www.acgpubs.org/RNP

\section{ORCID}

Danielle C. de Alencar: 0000-0003-4013-3978

Richardson A. de Almeida: 0000-0002-7476-3786

Felipe M. A. da Silva: 0000-0002-1809-1372

Emmanoel V. Costa: 0000-0002-0153-822X

Lívia M. Dutra: 0000-0002-9963-1093

Andersson Barison: 0000-0001-9381-8239

Helito Volpato: 0000-0003-1241-8052

Celso V. Nakamura: 0000-0002-9911-7369

Hector H. F. Koolen: 0000-0002-0181-348X

Afonso Duarte L. de Souza: 0000-0001-7007-3991

Maria Lúcia B. Pinheiro: 0000-0002-3196-4748 


\section{References}

[1] L.W. Chatrou, M.D. Pirie, R.H.J. Erkens, T.L.P. Couvreur, K.M.J. Neubig, R. Abbott, J.B. Mols, J.W. Maas, R.M.K. Saunders and M.W. Chase (2012). A new subfamilial and tribal classification of the pantropical flowering plant family Annonaceae informed by molecular phylogenetics, Botan. J. Linn. Soc. 169, 5-40.

[2] J.S.S. Quintans, B.M. Soares, R.P.C. Ferraz, A.C.A. Oliveira, T.B. Silva, L.R.A. Menezes, M.F.C. Sampaio, A.P.N. Prata, M. Moraes, C. Pessoa, A. Antoniolli, E.V. Costa and D. Bezerra (2013). Chemical constituents and anticancer effects of the essential oil from leaves of Xylopia Laevigata, Planta Med. 79, $123-130$

[3] Y. Nishiyama, M. Moriyasu, M. Ichimaru, K. Iwasa, A. Kato, S.G. Mathenge, P.B. Chalo-Mutiso and F.D. Juma (2006). Secondary and terciary isoquinoline alkaloids from Xylopia Parviflora, Phytochemistry 67, 2671-2675.

[4] I.C. Moreira, N.F. Roque, W. Vilegas, C.A. Zalewski, J.H.G. Lago and M. Funasaki (2013). Genus Xylopia (Annonaceae): chemical and biological aspects, Chem. \& Biodivers. 10, 1921-1943.

[5] A.O. Santos, P. Veiga-Santos, T. Ueda-Nakamura, B.P. Dias-Filho, D.B Sudatti, E.M. Bianco, R.C. Pereira and C.V. Nakamura (2010). Effect of elatol, isolated from red seaweed Laurencia dendroidea, on Leishmania amazonensis, Marine Drug. 8, 2733-2743.

[6] E.S. Gil, J.R. Paula, F.R.F Nascimento and J.C.B. Bezerra (2008). Produtos naturais com potencial leishmanicida, Rev. de Ciênc. Farmaceut. Básica Apl. 29, 223-230.

[7] M.L.B. Pinheiro, C.M. Xavier, A.D.L. Souza, D.M. Rabelo, C.L. Batista, R.L. Batista, E.V. Costa, F.R Campos, A. Barison, R.H. Valdez, T. Ueda-Nakamura and C.V. Nakamura (2009). Acanthoic acid and other constituents from the stem of Annona amazonica (Annonaceae), J. Brazil. Chem. Soc. 20, 10951102 .

[8] H.H.F. Koolen, E.R. Soares, F.M.A. Silva, A.A. Oliveira, A.Q.L. Souza, L.S. Medeiros, E. RodriguesFilho, B.C. Cavalcanti, C.O. Pessoa, M.O. Morais, M.J. Salvador and A.D.L. Souza (2013). Mauritic acid: a new dammarane triterpene from the roots of Mauritia flexuosa L.f. (Arecaceae), Nat. Prod. Res. 27, 2118-2125.

[9] F.M.A. Silva, B.R. Lima, E.R. Soares, R.A. Almeida, F.A. Silva-Filho, W.R. Corrêa, M.J. Salvador, A.Q.L. Souza, H.H.F. Koolen, A.D.L. Souza and M.L.B. Pinheiro (2015). Polycarpol in Unonopsis, Bocageopsis and Onychopetalum Amazonian species: Chemosystematical implications and antimicrobial evaluation, Rev. Brasil. Farmacog. 25, 11-15.

[10] R.F. Santos, I.R. Martins, F.S. Monteiro, R.A. Travassos, D.I. Janebro, J.F. Tavares, M.S. Silva and B.A. Silva (2012). Spasmolytic activity of trachylobanes ent-7 $\alpha$-acetoxytrachyloban-18-oic acid and ent-7 $\alpha$ hydroxytrachyloban-18-oic acid isolated from Xylopia langsdorfiana A. St-Hil. \& tul. (Annonaceae), Nat. Prod. Res. 26, 2335-2339.

[11] T.F. Stefanello, M.R. Panice, T. Ueda-Nakamura, M.H. Sarragiotto, R. Auzély-Velty and C.V. Nakamura (2014). N-Butyl-[1-(4-Methoxy)Phenyl-9H- $\beta$-Carboline]-3-carboxamide prevents cytokinesis in Leishmania amazonenses, Antimicrob. Agents Chemother. 58, 7112-7120.

[12] K. Yamasaki, H. Kohda, T. Kobayashi, R. Kasai and O. Tanaka (1976). Structures of stevia diterpeneglucosides: Application of ${ }^{13} \mathrm{C}$ NMR, Tetrahedron Lett. 13, 1005-1008.

[13] P.A. García, A..B. Oliveira and R. Batista (2007). Occurrence, biological activities and synthesis of kaurane diterpenes and their glycosides, Molecules 12, 455-483.

[14] A.G. Pacheco, P.M. Oliveira, D. Piló-Veloso and A.F.C. Alcântara (2009). ${ }^{13}$ C-NMR data of diterpenes isolated from Aristolochia species, Molecules 14, 1245-1262.

[15] S.T. Guetchueng, L. Nahar, K.J. Ritchie, F. M. D. Ismail, J.D. Wansi, A. Evans and S.D. Sarker (2017). Kaurane diterpenes from the fruits of Zanthoxylum leprieurii (Rutaceae), Rec. Nat. Prod. 11:3, 304-309

[16] J.E. Gurst (1991). NMR and the structure of D-Glucose. J. Chem Ed. 68, 1003-1004.

[17] E. Osório, G.J. Arangoa, N. Jiménez, F. Alzate, G. Ruiz, D. Gutiérrez, M.A. Paco, A. Giménez and S. Robledo (2007). Antiprotozoal and cytotoxic activities in vitro of Colombian Annonaceae, $J$. Ethnopharmacol. 111, 630-635.

[18] M. Takahashi, H. Fuchino, S. Sekita and M. Satake (2004). In vitro Leishmanicidal activity of some scarce natural products, Phytother. Res. 18, 573-578.

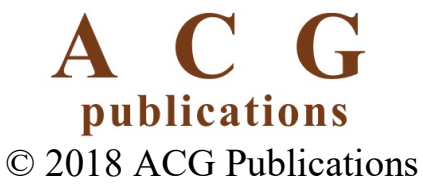

